\title{
UKURAN PERUSAHAAN, MODAL KERJA, DAN RETURN ON EQUITY (ROE) PADA INDUSTRI OTOMOTIF YANG TERDAFTAR DI BURSA EFEK INDONESIA (BEI) SELAMA PERIODE 2012-2015
}

$\mathrm{Fe} \mathrm{Fe}^{1}$, Arna Suryani ${ }^{2}$

\begin{abstract}
This research aims to find out how the effect of the firm size and working capital towards Return on Equity (ROE) in the automotive industry are listed on the Indonesia Stock Exchange (IDX) during 2012-2015 periods. Tthe data used are secondary data, which uses quantitative descriptive analysis method by using multiple linear regression analysis and statistical tests the F test and t test. Based on multiple linear regression analysis results with the data panel obtained equations $Y_{i t}=1746.027-6.932 X_{1 i t}+0.440 X_{2 i t}+\mu_{i t .}$ Based on simultaneous test $(F)$ Firm Size and Working Capital effect significantly to Return on Equity. Based on the partial test (t) Firm Size and Working Capital effect significantly to Return on Equity. The results of the $R$ Square is 0.151 or $15.1 \%$. Means of $84.9 \%$ explained by other factors outside of research. Keywords :Firm Size, Working Capital, Return on Equity
\end{abstract}

\section{PENDAHULUAN}

Pembangunan Ekonomi suatu bangsa merupakan pilar penting bagi terselenggaranya proses pembangunan di segala bidang. Sektor industri merupakan salah satu sektor yang berperan penting dalam pembangunan nasional. Kontribusi sektor industri terhadap pembangunan nasional dari tahun ke tahun menunjukkan kontribusi yang signifikan. Sektor industri memegang peran kunci sebagai mesin pembangunan karena sektor industri memiliki beberapa keunggulan dibandingkan sektor lain karena nilai kapitalisasi modal yang tertanam sangat besar, kemampuan menyerap tenaga kerja yang besar, juga kemampuan menciptakan nilai tambah (value added creation) dari setiap input atau bahan dasar yang diolah. Peran industri otomotif dan komponennya ternyata memberikan kontribusi yang cukup besar kepada perekonomian Indonesia. Industri ini mencatat peran sebesar $28 \%$, sedikit di bawah konstribusi industri makanan dan tembakau. Sektor ini terus bertumbuh secara positif. Gabungan Industri Kendaraan Bermotor Indonesia (Gaikindo) mencatat, penjualan mobil mengalami penigkatan dari 318 ribu unit di 2006 menjadi 1,2 juta di tahun 2013. Pada tahun 2014, tercatat jumlah mobil yang terjual di Indonesia sebanyak 1,2 juta unit. Pada tahun 2015 menurun 16\% setelah hanya berhasil menjual 1 juta unit. Hal ini terjadi karena pertumbuhan ekonomi Indonesia yang melambat. Di sini tantangan untuk semua perusahaan di sektor industri otomotif bagaimana manajemen perusahaan dapat menjaga sustainability (keberlanjutan) usaha.

Di dalam suatu perusahaan berbagai pihak terlibat yang masing-masing memiliki kepentingan terhadap tujuan perusahaan. Oleh sebab itu sangatlah perlu untuk mengetahui kondisi keuangan dan hasil usaha perusahaan tersebut. Informasi mengenai keuangan ini dapat diperoleh melalui laporan keuangan yang dapat menunjukkan perkembangan suatu perusahaan. Ditinjau dari sudut pandang manajemen, laporan keuangan merupakan media untuk mengomunikasikan

\footnotetext{
${ }^{1}$ Mahasiswi Magister Manajemen FE Unbari

${ }^{2}$ Dosen FE Universitas Batanghari
}

Ukuran Perusahaan, Modal Kerja, dan Return on Equity (ROE) pada Industri Otomotif yang Terdaftar di Bursa Efek Indonesia (BEI) Selama Periode 2012-2015 
kinerja keuangan perusahaan yang dikelolanya kepada pihak yang berkepentingan, sedangkan ditinjau dari sudut pandang pemakai, diharapkan dapat digunakan dalam pengambilan keputusan.

Skala perusahaan merupakan ukuran yang dipakai untuk mencerminkan besar kecilnya perusahaan yang didasarkan kepada total aset perusahaan. Perusahaan yang berukuran besar mempunyai berbagai kelebihan dibanding perusahaan berukuran kecil karena ada kemungkinan pengaruh skala dalam biaya dan return membuat perusahaan yang lebih besar dapat memperoleh lebih banyak laba. Namun laba optimal yang diharapkan oleh perusahaan tidak akan tercapai apabila perusahaan tersebut tidak dapat memenuhi kebutuhan dana untuk kebutuhan operasional perusahaan sehari-hari seperti pembelian bahan baku, pembayaran upah buruh, membayar utang, dan pembayaran lainnya. Dana untuk kebutuhan operasional perusahaan sehari-hari adalah modal kerja. Dengan modal kerja yang optimal, perusahaan akan mendapatkan keuntungan dan dapat beroperasi secara efektif dan efisien. Perusahaan pada umumnya memiliki tujuan akhir yang ingin dicapai yaitu memberikan pengembalian investasi, dengan keseluruhan modal yang disetor oleh pemegang saham yang digunakan untuk operasi perusahaan dalam menghasilkan keuntungan (Return on Equity) yang maksimal, bagi pemegang sahamnya dengan memperoleh laba yang maksimal pula.

Berdasarkan latar belakang tersebut di atas maka penelitian ini bertujuan untuk mengetahui bagaimana pengaruh Ukuran Perusahaan dan Modal Kerja terhadap Return on Equity (ROE) pada Industri Otomotif yang terdaftar di Bursa Efek Indonesia (BEI) selama periode 2012-2015.

Dengan tercapainya tujuan penelitian maka manfaat yang diharapkan oleh peneliti adalah sebagai berikut : 1) Bagi pengembangan ilmu manajemen keuangan, penelitian ini sebagai sarana penambah pengetahuan dan wawasan mengenai bagaimana pengaruh Ukuran Perusahaan dan Modal Kerja terhadap Return on Equity (ROE). 2) Bagi calon investor, penelitian ini dapat memberikan informasi apakah perusahaan-perusahaan dalam Industri Otomotif layak untuk ditanamkan investasi yang dinilai dari tiga variabel yaitu: Ukuran Perusahaan, Modal Kerja, dan Return on Equity (ROE).

\section{Landasan Teori}

\section{Analisis Rasio Keuangan}

Laporan keuangan menggambarkan kondisi keuangan dan hasil usaha satu perusahaan pada saat tertentu atau jangka waktu tertentu. Jenis laporan keuangan yang lazim dikenal adalah : Neraca, Laporan Laba/Rugi, Laporan Arus Kas, dan Laporan Perubahan Posisi Keuangan.

Rasio keuangan merupakan angka yang diperoleh dari hasil perbandingan dari satu akun laporan keuangan dengan akun lainnya yang mempunyai hubungan yang relevan dan signifikan. Analisis laporan keuangan merupakan seni untuk mengubah data dari laporan keuangan ke informasi yang berguna bagi pengambil keputusan. Umumnya rasio dapat dikelompokkan dalam 5 tipe dasar yaitu: rasio likuiditas, rasio leverage, rasio aktivitas, rasio profitabilitas, rasio nilai pasar.

\section{Ukuran Perusahaan}

Ukuran perusahaan pada dasarnya adalah pengelompokkan perusahaan ke dalam beberapa kelompok, diantaranya perusahaan besar, sedang dan kecil. Skala 
perusahaan merupakan ukuran yang dipakai untuk mencerminkan besar kecilnya perusahaan yang didasarkan kepada total aset perusahaan. Aktiva (aset) adalah harta atau kekayaan yang dimiliki oleh perusahaan, baik pada saat tertentu maupun periode tertentu.

Menurut teori critical, semakin besar skala perusahaan maka profitabilitas juga akan meningkat, tetapi pada titik atau jumlah tertentu ukuran perusahaan akhirnya akan menurunkan profit perusahaan. Teori critical menekankan pada pengendalian oleh pemilik perusahaan terhadap sumber daya perusahaan seperti aset, teknologi, kekayaan intelektual sebagai faktor-faktor yang menentukan ukuran perusahaan. Dengan adanya sumber daya yang besar, maka perusahaan dapat melakukan investasi baik untuk aktiva lancar maupun aktiva tetap dan juga memenuhi permintaan produk. Hal ini akan semakin memperluas pangsa pasar. Dengan adanya penjualan yang semakin meningkat, perusahaan dapat menutup biaya yang keluar pada saat proses produksi.

\section{Modal Kerja}

Modal kerja merupakan suatu analisa terhadap sumber dan penggunaan modal kerja sangat penting bagi penganalisa intern maupun ekstern. Modal kerja adalah dana yang diperlukan untuk operasi sehari-hari seperti pembelian bahan baku, pembayaran upah buruh, membayar utang, dan pembayaran lainnya. Modal kerja dalam suatu perusahaan tergantung atau dipengaruhi oleh faktor-faktor yaitu: sifat atau type dari perusahaan, waktu yang dibutuhkan untuk memproduksi atau memperoleh barang yang akan dijual harga persatuan barang tersebut, syarat pembelian bahan atau barang dagangan, syarat penjualan, dan tingkat perputaran persediaan.

Modal kerja harus dikelola dengan baik, karena pengelolaan modal kerja itu memiliki beberapa tujuan seperti mencapai likuiditas yang cukup, meminimalkan resiko dan memperbesar nilai perusahaan. Tingkat profitabilitas yang rendah bila dihubungkan dengan modal kerja dapat menunjukkan kemungkinan rendahnya volume penjualan dibandingkan dengan ongkos yang digunakan, sehingga untuk menghindari itu diharapkan adanya pengelolaan modal kerja yang tepat di dalam perusahaan. Perusahaan yang dikatakan memiliki tingkat profitabilitas yang tinggi berarti tinggi pula efisiensi penggunaan modal kerja yang digunakan perusahaan tersebut.

\section{Return On Equity (ROE)}

Return on Equity (ROE) adalah perbandingan antara jumlah laba yang tersedia bagi pemilik modal sendiri di satu pihak dengan jumlah modal sendiri yang menghasilkan laba tersebut di lain pihak atau dengan kata lain profitabilitas modal sendiri adalah kemampuan suatu perusahaan dengan modal sendiri yang bekerja di dalamnya untuk menghasilkan keuntungan. ${ }^{[2]}$ Return on Equity (ROE) merupakan rasio yang sering dipergunakan oleh pemegang saham untuk menilai kinerja perusahaan yang bersangkutan.

\section{Kerangka Pemikiran}

Perusahaan dengan ukuran besar memiliki akses lebih besar dan luas untuk mendapat sumber pendanaan dari luar, semakin besar skala perusahaan maka profitabilitas juga akan meningkat, tetapi pada titik atau jumlah tertentu ukuran perusahaan akhirnya akan menurunkan profit perusahaan. Modal kerja yang cukup sangat penting bagi suatu perusahaan karena dengan modal kerja yang cukup itu memungkinkan bagi perusahaan untuk beroperasi dengan seekonomis mungkin dan perusahaan tidak mengalami kesulitan atau menghadapi bahaya- 
bahaya yang mungkin timbul karena adanya krisis keuangan.Tingkat profitabilitas yang rendah bila dihubungkan dengan modal kerja dapat menunjukkan kemungkinan rendahnya volume penjualan dibandingkan dengan ongkos yang digunakan, sehingga untuk menghindari itu diharapkan adanya pengelolaan modal kerja yang tepat di dalam perusahaan. Perusahaan yang dikatakan memiliki tingkat profitabilitas yang tinggi berarti tinggi pula efisiensi penggunaan modal kerja yang digunakan perusahaan tersebut. Berdasarkan uraian di atas maka dapat digambarkan bagan kerangka pemikiran sebagai berikut:

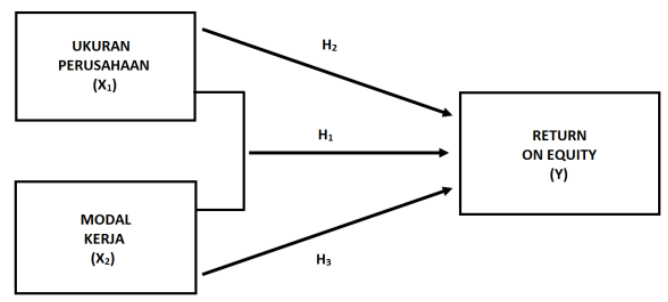

Gambar: Bagan Kerangka Pemikiran

\section{Hipotesis Penelitian}

Dari tinjauan teori dan kerangka pemikiran maka hipotesis dalam penelitian ini sebagai berikut:

1. Ukuran Perusahaan dan Modal Kerja berpengaruh secara simultan dan signifikan terhadap Return on Equity (ROE) pada Industri Otomotif yang terdaftar di Bursa Efek Indonesia (BEI) selama periode 2012 - 2015.

2. Ukuran Perusahaan berpengaruh secara parsial dan signifikan terhadap Return on Equity (ROE) pada Industri Otomotif yang terdaftar di Bursa Efek Indonesia (BEI) selama periode 2012 - 2015.

3. Modal Kerja berpengaruh secara parsial dan signifikan terhadap Return on Equity (ROE) pada Industri Otomotif yang terdaftar di Bursa Efek Indonesia (BEI) selama periode $2012-2015$.

\section{METODOLOGI PENELITIAN}

\section{Jenis dan Sumber Data}

Jenis data dalam penelitian ini adalah data sekunder berupa laporan keuangan Industri Otomotif selama periode 2012-2015 yang bersumber dari Bursa Efek Indonesia.

\section{Metode Pengumpulan Data}

Untuk mendapatkan data yang diperlukan dalam penelitian ini dilakukan dengan cara library research, yaitu penelitian ke pustakaan yang dilakukan dengan cara mempelajari teori-teori dari literatur-literatur dan laporan-laporan yang ada relevansinya dengan masalah pokok penelitian.

\section{Populasi dan Sampel}

Dari populasi sebanyak 18 perusahaan dalam industri otomotif yang terdaftar di Bursa Efek Indonesia (BEI), diambil 11 sampel perusahaan yang memenuhi kriteria dengan teknik purposive sampling.

\section{Operasional Variabel}


Variabel dalam penelitian ini dikelompokkan menjadi variabel dependen (terikat) dan variabel independen (bebas) yang diuraikan sebagai berikut :

Tabel 1. Operasional Variabel

\begin{tabular}{ccc}
\hline No & Variabel & Rumus \\
\hline & Ukuran & Size $=$ Ln (Total Aktiva) \\
1 & Perusahaan & \\
& $\left(\mathrm{X}_{1}\right)$ & \\
& Modal Kerja & Modal Kerja = Aktiva Lancar - Hutang \\
2 & $\left(\mathrm{X}_{2}\right)$ & Lancar \\
& Return On & $\mathrm{ROE}=\frac{\text { Laba Bersih Setelah Pajak }}{\text { Ekuitas }} \times 100 \%$ \\
3 & Equity & \\
& $(\mathrm{Y})$ & \\
\end{tabular}

\section{Metode Pengolahan Data}

Penelitian dilakukan dengan menggunakan metode analisis deskriptif kuantitatif. Alat analisis dengan menggunakan analisis regresi linier berganda dengan data panel, dalam hal ini perhitungan menggunakan program SPSS (Statistical Package for Service Solutions).

\section{Alat Analisis \\ Uji Asumsi Klasik}

Untuk memperoleh model regresi yang memberikan hasil Best Linear Unbiased Estimator (BLUE), model tersebut perlu diuji asumsi klasik dengan metode Ordinary Least Square (OLS) atau pangkat kuadrat terkecil biasa. Model regresi dikatakan BLUE apabila tidak terdapat Normalitas, Multikolinieritas, Heteroskedastisitas dan Autokorelasi.

Uji normalitas dimaksudkan untuk menghindari terjadinya bias, model regresi yang baik adalah memiliki distribusi data normal atau mendekati normal. ${ }^{[4]}$ Menggunakan Sampel Kolmogorov-smirnov. Uji multikolinieritas bertujuan menguji apakah dalam regresi ditemukan adanya korelasi antarvariabel independen. Model regresi yang baik seharusnya tidak mengandung korelasi diantara variabel-variabel independen. Jika ada korelasi yang tinggi diantara variabel-variabel independen, maka hubungan dengan variabel dependen menjadi terganggu. Apabila nilai tolerance di atas 0,1 dan nilai Variance Inflation Factor (VIF) di bawah 10, maka dapat disimpulkan bahwa model regresi bebas dari multikolinieritas.

Uji heteroskedastisitas bertujuan menguji apakah dalam regresi terjadi ketidaksamaan varians dari residual satu pengamatan ke pengamatan yang lain. Model regresi yang baik adalah yang homoskedastisitas. Untuk mendeteksinya dilakukan dengan melihat grafik scatterplot antara nilai prediksi variabel independen (ZPRED) dengan residualnya (SRESID).

Uji autokorelasi dimaksudkan untuk menguji apakah dalam suatu model regresi linier terdapat korelasi antara kesalahan pengganggu pada periode t dengan kesalahan pada periode $\mathrm{t}-1$ (sebelumnya). Untuk mendeteksi ada tidaknya autokorelasi, maka dilakukan pengujian Durbin-Watson (DW).

\section{Analisis Regresi Linier Berganda}

Data yang diperoleh dalam penelitian ini akan dianalisis dengan menggunakan alat analisis regresi linier berganda dengan data panel dengan 
asumsi intercept dan koefisien slope konstan sepanjang waktu yang diformulasikan sebagai berikut :

$\log Y_{\text {it }}=\beta_{0}+\beta_{1} \log X_{1 i t}+\beta_{2} \log X_{2 i t}+\mu_{\text {it }}$

Dimana :

$\log Y_{\text {it }} \quad: \log$ (Modal Kerja)

$\log \mathrm{X}_{1 \mathrm{it}} \quad: \log ($ Ukuran Perusahaan)

$\log \mathrm{X}_{2 \mathrm{it}} \quad: \log$ (Return On Equity)

$\beta_{0} \quad$ : Konstanta

$\beta_{1}, \beta_{2} \quad$ : Koefisien regresi

$\mu_{\text {it }} \quad:$ Error

Pada persamaan tersebut telah ditransformasikan menjadi logaritma untuk menyamakan satuan dari ketiga variabel penelitian.

\section{Uji Hipotesis}

\section{Uji Statistik F}

Uji F digunakan untuk menguji pengaruh secara bersama-sama (simultan) antara Ukuran Perusahaan dan Modal Kerja terhadap Return on Equity (ROE) pada Industri Otomotif yang terdaftar di Bursa Efek Indonesia (BEI). Langkahlangkah dalam uji statistik F antara lain :

1. Membuat rumusan hipotesis

- $\mathrm{H}_{0} ; \mathrm{b}_{1}=\mathrm{b}_{2}=0$ artinya tidak ada pengaruh signifikan secara simultan dari Ukuran Perusahaan dan Return on Equity (ROE) terhadap Modal Kerja;

- $\mathrm{H}_{\mathrm{a}} ; \mathrm{b}_{1} \neq \mathrm{b}_{2} \neq 0$ artinya ada pengaruh yang signifikan secara simultan dari Ukuran Perusahaan dan Return on Equity (ROE) terhadap Modal Kerja.

2. Tentukan tingkat signifikasi dengan $\alpha=5 \%$ atau $\alpha=0,05$.

3. Kriteria keputusan :

- Jika $\mathrm{F}_{\text {hitung }}>\mathrm{F}$ tabel : berarti $\mathrm{H}_{0}$ ditolak dan $\mathrm{H}_{\mathrm{a}}$ diterima;

- Jika $\mathrm{F}_{\text {hitung }}<\mathrm{F}$ tabel : berarti $\mathrm{H}_{0}$ diterima dan $\mathrm{H}_{\mathrm{a}}$ ditolak.

\section{Uji Statistik t}

Uji t digunakan untuk menguji pengaruh secara parsial antara Ukuran Perusahaan dan Modal Kerja terhadap Return on Equity (ROE) pada Industri Otomotif yang terdaftar di Bursa Efek Indonesia (BEI). Langkah-langkah dalam uji statistik t antara lain:

1. Membuat rumusan hipotesis

- $\mathrm{H}_{0} ; \mathrm{b}_{1}=0$ artinya tidak ada pengaruh signifikan dari Ukuran Perusahaan terhadap Return on Equity (ROE);

- $\mathrm{H}_{\mathrm{a}} ; \mathrm{b}_{1} \neq 0$ artinya ada pengaruh signifikan dari Ukuran Perusahaan terhadap Return on Equity (ROE);

- $\mathrm{H}_{0} ; \mathrm{b}_{2}=0$ artinya tidak ada pengaruh signifikan dari Modal Kerja terhadap Return on Equity (ROE);

- $\mathrm{H}_{\mathrm{a}} ; \mathrm{b}_{2} \neq 0$ artinya ada pengaruh signifikan dari Modal Kerja terhadap Return on Equity (ROE).

2. Tentukan tingkat signifikan dengan $\alpha=5 \%$ atau $\alpha=0,05$.

3. Kriteria keputusan :

- Jika $\mathrm{t}_{\text {hitung }}>\mathrm{t}$ tabel : berarti $\mathrm{H}_{0}$ ditolak dan $\mathrm{H}_{\mathrm{a}}$ diterima;

- Jika $\mathrm{t}_{\text {hitung }}<\mathrm{t}_{\text {tabel }}$ : berarti $\mathrm{H}_{0}$ diterima dan $\mathrm{H}_{\mathrm{a}}$ ditolak.

\section{Koefisien Determinasi}

Koefisien determinasi adalah salah satu nilai statistik yang dapat digunakan untuk mengetahui apakah data hubungan pengaruh antara variabel independen (X) 
dan variabel dependen (Y). nilai koefisien determinasi menunjukkan presentase variasi nilai variabel dependen yang dapat dijelaskan oleh persamaan regresi $\left(\mathrm{R}^{2}\right)$. Semakin besar koefisien determinasi menunjukkan semakin baik kemampuan $\mathrm{X}$ mempengaruhi Y.

\section{Uji Asumsi Klasik}

\section{HASIL DAN PEMBAHASAN}

Berdasarkan hasil penelitian, nilai Kolmogorof-smirov 0,822 berarti di atas 0,05 sehingga dapat disimpulkan data dalam model regresi telah terdistribusi secara normal. Nilai VIF sebesar 5,310 yang berarti di bawah 10. Dan angka tolerance sebesar 0,188 yang berarti di atas 0,1 . Sehingga dapat disimpulkan tidak terjadi multikolinieritas antarvariabel bebas.

Gambar scatterplot menunjukkan bahwa titik-titik menyebar secara acak, baik diatas maupun dibawah angka 0 pada sumbu Y. Hal ini menunjukkan bahwa tidak terjadi heteroskedastisitas pada model regresi.

Angka Durbin Watson sebesar 1,818; Terletak diantara -2 sampai 2 maka diambil kesimpulan bahwa model regresi ini tidak terjadi autokorelasi; Sehingga dapat dikatakan model regresi dalam penelitian ini layak untuk memprediksi besarnya Return on Equity (ROE).

\section{Analisis Regresi Linier Berganda}

Berdasarkan hasil analisis regresi linier berganda dengan data panel (Tabel 2) diperoleh persamaan sebagai berikut:

$\mathrm{Y}_{\mathrm{it}}=1746,027-6,932 \mathrm{X}_{1 \mathrm{it}}+0,440 \mathrm{X}_{2 \mathrm{it}}+\mu_{\mathrm{it}}$

Dari persamaan di atas maka dapat dianalisis sebagai berikut :

1. Konstanta sebesar 1.746,027 menunjukkan jika variabel Ukuran Perusahaan dan Modal Kerja konstan atau sama dengan nol maka Return on Equity (ROE) bernilai 1.746,027.

2. Perubahan Ukuran Perusahaan mempunyai nilai koefisien regresi sebesar 6,932. koefisien bertanda negatif, ini berarti bahwa setiap peningkatan Ukuran Perusahaan sebesar 1 satuan akan mengakibatkan penurunan Return on Equity (ROE) sebesar 6,932.

3. Perubahan Modal Kerja mempunyai nilai koefisien regresi sebesar 0,440. Koefisien bertanda positif, ini berarti bahwa setiap peningkatan Modal Kerja sebesar 1 satuan akan mengakibatkan peningkatan Return on Equity (ROE) sebesar 0,440.

Tabel 2. Hasil Analisis Regresi Linier Berganda

\section{Coefficients $^{\mathrm{a}}$}

\begin{tabular}{lrrr}
\hline Model & \multicolumn{2}{c}{ Unstandardized } & Sig. \\
& \multicolumn{2}{c}{ Coefficients } & \\
& \multicolumn{1}{c}{ B } & Std. Error & \\
\hline (Constant) & 1746.027 & 665.290 & .012 \\
1 Firm Size & -6.932 & 2.909 & .022 \\
Net Working Capital & .440 & .163 & .010 \\
\hline a. Dependent Variable: ROE & & &
\end{tabular}




\section{Uji Hipotesis}

\section{Uji F}

Berdasarkan hasil penelitian (Tabel 3) yang dilakukan dengan membandingkan nilai $F_{\text {hitung }}$ dan $\mathrm{F}$ tabel, maka pengujian hipotesis pertama dijelaskan sebagai berikut:

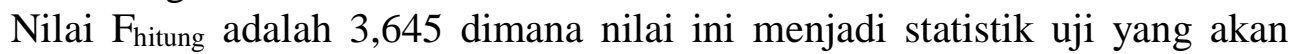
dibandingkan dengan nilai $F$ dari tabel. Dari tabel $F$ untuk $\alpha=0,05$ dengan derajat bebas pembilang 2 dan derajat bebas penyebut 41, diperoleh nilai $F_{\text {tabel }}$ sebesar 3,23 ; Karena $F_{\text {hitung }}(3,645)$ besar dari $F_{\text {tabel }}(3,23)$ maka dengan tingkat kekeliruan $5 \%(\alpha=0,05), \mathrm{H}_{0}$ ditolak dan $\mathrm{H}_{\mathrm{a}}$ diterima. Artinya dengan tingkat kepercayaan 95\% dapat disimpulkan bahwa ada pengaruh signifikan secara simultan dari Ukuran Perusahaan dan Modal Kerja terhadap Return on Equity (ROE) dan hipotesis pertama diterima.

Hasil ini menunjukkan bahwa informasi mengenai variabel Ukuran Perusahaan dan Modal Kerja dapat dipergunakan secara bersama-sama untuk memprediksi besarnya tingkat kemampuan perusahaan dalam menghasilkan keuntungan dari modal sendiri yang dimiliki (Return on Equity).

Tabel 3. Uji Statistik F

\begin{tabular}{llrrrr} 
ANOVA $^{\mathbf{a}}$ & & & & \\
\hline Model & df & \multicolumn{1}{c}{$\begin{array}{c}\text { Mean } \\
\text { Square }\end{array}$} & F & Sig. \\
\hline \multirow{2}{*}{1} & Regression & 2 & 23688.299 & 3.645 & $.035^{\text {b }}$ \\
& Residual & 41 & 6498.934 & & \\
& Total & 43 & & & \\
\hline
\end{tabular}

a. Dependent Variable: ROE

b. Predictors: (Constant), Net Working Capital, Firm Size

\section{Uji t}

Berdasarkan hasil penelitian (Tabel 4) yang dilakukan dengan membandingkan nilai $t_{\text {hitung }}$ dengan $t_{\text {tabel }}$, maka dijelaskan sebagai berikut :

1. Pengujian hipotesis kedua

Nilai $t_{\text {hitung }}$ Ukuran Perusahaan $\left(\mathrm{X}_{1}\right)$ sebesar $-2,383$ dan $\mathrm{t}_{\text {tabel }}$ sebesar 1,645 dari hasil perbandingan maka diketahui $t_{\text {hitung }}$ lebih besar dari $t_{\text {tabel }}\left(t_{\text {hitung }}>\right.$

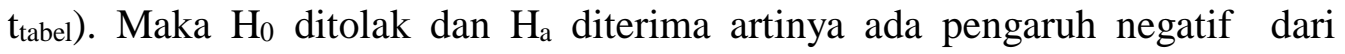
Ukuran Perusahaan $\left(\mathrm{X}_{1}\right)$ terhadap Return on Equity (Y). Dengan membandingkan besarnya angka taraf signifikan (Sig.) penelitian sebesar 0,022 maka 0,022 < 0,05 sehingga dapat dikatakan bahwa ada pengaruh signifikan secara parsial dari Ukuran Perusahaan $\left(\mathrm{X}_{1}\right)$ terhadap Return on Equity $(\mathrm{Y})$ pada Industri Otomotif yang terdaftar di Bursa Efek Indonesia (BEI) selama periode 2012-2015 dan hipotesis diterima.

Hasil ini menunjukkan bahwa informasi mengenai variabel Ukuran Perusahaan dapat dipergunakan untuk memprediksi besarnya tingkat kemampuan perusahaan dalam menghasilkan keuntungan dari modal sendiri yang dimiliki (Return on Equity). Ternyata terbukti bahwa dengan total aset yang besar (ukuran perusahaan dengan skala besar) dari suatu perusahaan tidak menjamin bahwa pada titik tersebut akan memberikan profit yang maksimal malah hanya akan menurunkan profit perusahaan tersebut. Hal ini dapat terjadi apabila manajemen 
perusahaan tidak dapat mengalokasikan dengan baik dan benar bagaimana penggunaan dari aset tersebut.

2. Pengujian hipotesis ketiga

Nilai thitung Modal Kerja $\left(\mathrm{X}_{2}\right)$ sebesar 2,698 dan $\mathrm{t}_{\text {tabel }}$ sebesar 1,645; dari

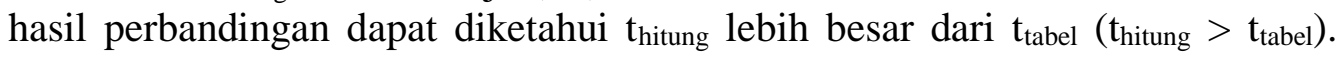
Maka $\mathrm{H}_{0}$ ditolak dan $\mathrm{H}_{\mathrm{a}}$ diterima; Dengan membandingkan besarnya angka taraf signifikan (Sig.) penelitian sebesar 0,010 maka 0,010<0,05 sehingga dapat dikatakan bahwa ada pengaruh signifikan secara parsial dari Modal Kerja $\left(\mathrm{X}_{2}\right)$ terhadap Return on Equity (Y) pada Industri Otomotif yang terdaftar di Bursa Efek Indonesia (BEI) selama periode 2012-2015 dan hipotesis diterima.

Hasil ini menunjukkan bahwa informasi mengenai variabel Modal Kerja dapat dipergunakan untuk memprediksi besarnya tingkat kemampuan perusahaan dalam menghasilkan keuntungan dari modal sendiri yang dimiliki (Return on Equity). Pengelolaan modal kerja yang efisien dapat memberikan keuntungan atau meningkatkan laba bagi perusahaan. Efisiensi dalam modal kerja sangat diperlukan untuk menjamin kelangsungan atau keberhasilan jangka panjang dan untuk mencapai tujuan perusahaan secara keseluruhan yang dalam hal ini memperbesar keuntungan bagi pemilik. Tingkat profitabilitas yang rendah bila dihubungkan dengan modal kerja dapat menunjukkan kemungkinan rendahnya volume penjualan dibandingkan dengan ongkos yang digunakan, sehingga untuk menghindari itu diharapkan adanya pengelolaan modal kerja yang tepat di dalam perusahaan. Perusahaan yang dikatakan memiliki tingkat profitabilitas yang tinggi berarti tinggi pula efisiensi penggunaan modal kerja yang digunakan perusahaan tersebut.

Namun, selama 4 tahun periode penelitian ini, tingkat keuntungan dari modal sendiri yang dimiliki perusahaan menunjukkan penurunan secara berkala. Hal ini dapat menggambarkan bahwa modal kerja perusahaan dalam sektor industri otomotif juga belum dikelola sepenuhnya dengan baik dan benar oleh manajemen perusahaan.

Tidak menutup kemungkinan hal tersebut juga karena faktor dari eksternal. Pada tahun 2015, jumlah mobil terjual di Indonesia menurun 16\% dari tahun sebelumnya. Hal ini terjadi karena daya beli masyarakat yang menurun, bukan karena harga BBM yang meningkat.

Di sinilah tantangan untuk semua perusahaan di sektor industri otomotif bagaimana mereka dapat mempertahankan keberlanjutan (sustainability) usahanya.

Tabel 4. Uji Statistik t

Coefficients $^{\text {a }}$

\begin{tabular}{|c|c|c|c|c|}
\hline \multirow[t]{3}{*}{ Model } & \multirow[t]{3}{*}{$\mathrm{t}$} & \multirow[t]{3}{*}{ Sig. } & \multicolumn{2}{|c|}{$\begin{array}{l}\text { 95.0\% Confidence } \\
\text { Interval for B }\end{array}$} \\
\hline & & & Lower & Upper \\
\hline & & & Bound & Bound \\
\hline (Constant) & 2.624 & .012 & 402.447 & 3089.607 \\
\hline Firm Size & -2.383 & .022 & -12.806 & -1.058 \\
\hline Net Working Capital & 2.698 & .010 & .111 & .770 \\
\hline
\end{tabular}

a. Dependent Variable: ROE 


\section{Koefisien Determinasi $\left(\mathbf{R}^{2}\right)$}

Berdasarkan hasil penelitian diperoleh angka $\mathrm{R}$ square sebesar 0,151 hal itu berarti bahwa variasi perubahan $\mathrm{Y}$ dipengaruhi oleh perubahan $\mathrm{X}_{1}$ dan $\mathrm{X}_{2}$ sebesar 15,1\%. Jadi besarnya pengaruh Ukuran Perusahaan dan Modal Kerja terhadap Return on Equity (ROE) adalah sebesar 15,1\%, sedangkan sisanya sebesar 84,9\% dipengaruhi oleh faktor lain diluar penelitian ini.

\section{SIMPULAN DAN SARAN \\ Simpulan}

Berdasarkan penelitian yang telah dilakukan maka dapat diambil kesimpulan sebagai berikut :

1. Secara simultan menunjukkan bahwa terdapat pengaruh yang signifikan antara variabel Ukuran Perusahaan dan Modal Kerja terhadap Return on Equity (ROE). Artinya informasi mengenai variabel Ukuran Perusahaan dan variabel Modal Kerja dapat dipergunakan secara bersama-sama untuk memprediksi besarnya variabel Return on Equity (ROE). Sehingga hipotesis pertama yang menyatakan bahwa terdapat pengaruh antara Ukuran Perusahaan dan Modal Kerja terhadap Return on Equity (ROE) diterima.

2. Secara parsial menunjukkan bahwa variabel Ukuran Perusahaan berpengaruh signifikan dan mempunyai hubungan negatif terhadap Return on Equity (ROE). Hal ini menjelaskan bahwa jika terjadi perubahan kenaikan pada variabel Ukuran Perusahaan sebesar 1 satuan maka akan mengakibatkan penurunan Return on Equity sebesar 6,932. Hipotesis kedua yang menyatakan bahwa terdapat pengaruh antara Ukuran Perusahaan dengan Return on Equity (ROE) diterima.

3. Secara parsial menunjukkan bahwa variabel Modal Kerja berpengaruh signifikan terhadap Return on Equity (ROE). Hal ini menjelaskan bahwa jika terjadi perubahan kenaikan pada variabel Modal Kerja sebesar 1 satuan maka akan mengakibatkan peningkatan Return on Equity sebesar 0,440. hipotesis ketiga yang menyatakan bahwa terdapat pengaruh antara Modal Kerja dengan Return on Equity (ROE) diterima.

\section{Saran}

Dari kesimpulan yang diambil penulis dalam kesempatan ini dapat memberikan saran sebagai berikut:

1. Bagi penelitian selanjutnya sebaiknya menambahkan/menggunakan variabel independen lain selain yang digunakan dalam penelitian ini, serta menambahkan periode pengamatan untuk memperoleh informasi mengenai variabel yang hadal untuk melakukan penilaian yang akurat.

2. Bagi penelitian selanjutnya hendaknya menggunakan perusahaan sektor industri yang berbeda untuk melihat apakah Ukuran Perusahaan dan Modal Kerja terhadap Return on Equity (ROE) berpengaruh di sektor usaha yang berbeda. Sehingga, dapat diperoleh hasil yang lebih valid guna menguji pengaruh Ukuran Perusahaan dan Modal Kerja terhadap Return on Equity (ROE).

3. Bagi perusahaan di sektor industri otomotif, agar dapat mempertahankan keberlanjutan usaha dan mendapatkan profit yang maksimal maka perlu diperbaiki dari sisi pengelolaan aset dan modal kerja yang dimiliki. Sehingga dapat menghadapi ancaman (threat) baik dari internal maupun eksternal. 
4. Bagi calon investor, penelitian ini memberikan informasi bahwa tingkat Return on Equity (ROE) perusahaan-perusahaan dalam industri otomotif dapat diukur dengan variabel Ukuran Perusahaan dan Modal Kerja. Sehingga calon investor hendaknya dapat memprediksi perusahaan mana yang layak untuk ditanamkan investasi.

\section{DAFTAR PUSTAKA}

Agus, R. Sartono (2010), Manajemen Keuangan Teori dan Aplikasi, Edisi 4, Yogyakarta: BPFE

Bambang, Riyanto (2011), Dasar-dasar Pembelanjaan Perusahaan, Edisi 5, Yogyakarta: BPFE

Harahap, Sofyan Syafri (2010), Analisis Kritis Atas Laporan Keuangan, Jakarta: Rajawali Persada

Imam, Ghozali (2006), Aplikasi Analisis Multivariate dengan Program SPSS, Cetakan 4, Semarang: Badan Penerbit Universitas Diponegoro

Kasmir (2012), Analisis Laporan Keuangan, Jakarta: PT. Raja Grafindo Persada

S Munawir (2010), Analisis Laporan Keuangan, Edisi 4, Yogyakarta: PT. Liberty

Susan, Irawati (2006), Manajemen Keuangan, Pustaka: Bandung 